\title{
Rates of urea with or without urease inhibitor for topdressing wheat
}

\author{
Marcelo Curitiba Espindula ${ }^{1 *}$,Valterley Soares Rocha ${ }^{2}$, Moacil Alves de Souza ${ }^{2}$, Marcela Campanharo ${ }^{3}$, \\ and Guilherme de Sousa Paula ${ }^{2}$
}

The urease inhibitor NBPT(N-(n-butyl) thiophosphoric triamide) is a management alternative to increase urea efficiency in topdressing because it reduces $\mathrm{NH}_{3}$ volatilization. The objective of this study was to evaluate $\mathrm{N}$ recovery and yield performance of wheat (Triticum aestivum L.) 'BRS 254' fertilized with different urea or urea + NBPT rates in topdressing. The experiment was conducted from May to September 2007 in Viçosa, Minas Gerais, Brazil. Treatments followed a $5 \times 2+1$ factorial design consisting of five $\mathrm{N}$ fertilizer rates $\left(30,60,90,120\right.$, and $\left.150 \mathrm{~kg} \mathrm{ha}^{-1}\right)$ as urea or urea + NBPT $\left(\right.$ Agrotain $^{\circledR}$ ) applied as topdressing and a control without $\mathrm{N}$. The experiment was a randomized complete block design with four replicates. Adding NBPT to urea resulted in better $\mathrm{N}$ utilization by wheat plants. The $100 \mathrm{~kg} \mathrm{~N}^{-1}$ topdressing rate provided the best apparent $\mathrm{N}$ recovery by wheat plants, whereas $90 \mathrm{~kg} \mathrm{ha}^{-1}$ provided the best $\mathrm{N}$ use efficiency.

Key words: Triticum aestivum, nitrogen fertilization, $\mathrm{NH}_{3}$ volatilization, NBPT, N-(n-butyl)thiophosphoric triamide.

\section{INTRODUCTION}

Urea is the main form of $\mathrm{N}$ fertilizer used in agriculture due to its high $\mathrm{N}$ concentration (45\%), which allows low cost transportation and application, high solubility, low corrosivity, and ease of mixing with other sources.

When applied to the soil, urea is subjected to urease enzyme activity (Malhi et al., 2001), which is found in plants, bacteria, fungi, algae, and invertebrates. It exerts a single catalytic functional though there are different protein structures and hydrolysis of urea produces ammonia and carbonic acid (Krajewska, 2009). Ammonia produced in the reaction can be lost to the atmosphere mainly when it is close to the soil surface (Malhi et al., 2001). Therefore, urea applied to the soil is subjected to $\mathrm{N}$ loss by $\mathrm{NH}_{3}$ volatilization (Gioacchini et al., 2002; Costa et al., 2003; Martha Jr. et al., 2004; Vitti et al., 2007).

Losses by volatilization increase with factors that increase evaporation, such as high air and soil temperatures and strong winds. Urea-based fertilizer used under mild temperature conditions, light winds, and good probability of rain tends to reduce $\mathrm{NH}_{3}$ volatilization (Malhi et al., 2001).

Using urease activity inhibitors can be a management alternative to increase urea efficiency on the surface by reducing volatilization (Grant and Bailey, 1999). Among these inhibitors, NBPT (N-(n-butyl) thiophosphoric triamide) has been reported to be promising in reducing

${ }^{1}$ Empresa Brasileira de Pesquisa Agropecuária, Embrapa Rondônia, BR 364, km 5.5, 76815-800, Porto Velho, Rondônia, Brasil. *Corresponding author (marcelo.espindula@embrapa.br).

${ }^{2}$ Universidade Federal de Viçosa, Departamento de Fitotecnia, Av. P.H. Rolfs, s/n, 36570-000, Viçosa, Minas Gerais, Brasil.

${ }^{3}$ Faculdades Integradas Aparício Carvalho, Rua Araras 241, Jardim Eldorado, 78912-640, Porto Velho, Rondônia, Brasil.

Received: 10 July 2012.

Accepted: 3 February 2013.

doi:10.4067/S0718-58392013000200012.
$\mathrm{NH}_{3}$ volatilization in crops such as sugar cane without straw removal by burning (Cantarella et al., 2008), wheat (Gioacchini et al., 2002), barley (Hordeum vulgare L.), and durum wheat (Triticum durum L.) (Malhi et al., 2001).

Nitrogen rates can influence agronomic characteristics and yield components of wheat plants in different ways. Lopes-Bellido et al. (2004) report an exponential increase for the yield of wheat grains subjected to variations from 0 to $300 \mathrm{~kg} \mathrm{~N} \mathrm{ha}^{-1}$. Espindula et al. (2009) found quadratic responses of grain yield for rates that varied from 30 to $150 \mathrm{~kg} \mathrm{ha}^{-1}$. Espindula et al. (2011) reported higher grain yield of wheat 'Pioneiro' (adapted to Brazilian Savanna) with $100 \mathrm{~kg} \mathrm{~N} \mathrm{ha}^{-1}$ in the same soil and similar climatic conditions. Corroborating these results, Espindula et al. (2010) reported maximum grain yield with $96.8 \mathrm{~kg} \mathrm{~N}$ $\mathrm{ha}^{-1}$ with the same cultivar. These authors found yields of 4800 and $5000 \mathrm{~kg} \mathrm{ha}^{-1}$ (Espindula et al., 2011). In Brazilian Savanna conditions, Trindade et al. (2006) report a maximum grain yield of $5733 \mathrm{~kg} \mathrm{ha}^{-1}$ (maximum technical efficiency) with $73 \mathrm{~kg} \mathrm{~N}^{-1} \mathrm{a}^{-1}$ (economic rate).

The study of $\mathrm{N}$ rates using urea with urease inhibitor becomes even more important because there may be an interaction of the effects besides the isolated effects. The inhibitor can produce $\mathrm{NH}_{3}$ volatilization due to its activity on urease (Manunza et al., 1999), while the high urea concentration can saturate the sites of urease action (Longo and Melo, 2005); this retards urea hydrolysis and reduces losses by volatilization. However, rates can also excessively increase surface $\mathrm{pH}$ and promote volatilization (Rodrigues and Kiehl, 1992). The isolated effects or the combination of effects can eventually promote different responses in production components and wheat plant grain yield.

The aim of the present study was to evaluate $\mathrm{N}$ recovery and productive performance of wheat 'BRS 254' subjected to rates of urea or urea + NBPT applied for topdressing wheat. 


\section{MATERIALS AND METHODS}

The experiment was conducted at the Estação Experimental Prof. Diogo Alves de Mello of the Universidade Federal de Viçosa (UFV) in Viçosa, $\left(20^{\circ} 45^{\prime}\right.$ S, 42 $2^{\circ} 1^{\prime}$ 'W; 650 m.a.s.l.), Minas Gerais, Brazil from May to September 2007. Daily data of maximum, average, and minimum temperatures, relative air humidity, wind speed, and rainfall were provided by the main weather station of the Agricultural Engineering Department of the UFV during the experimental period (Figure 1).

The soil of the experimental area is an Oxisol which has been used for cultivation of soybean (summer) and wheat (winter) in the last few years. The chemical characteristics of this soil were determined at a 0 to $20 \mathrm{~cm}$ depth (Table 1 ).

Soil was prepared by plowing along with two harrowing procedures, and sowing fertilization was 250 $\mathrm{kg} \mathrm{ha}^{-1}$ of the commercial 08-28-16 formula. Seed density of wheat 'BRS 254' was 350 useful seeds per square meter sown with a suitable seeding machine for experimental plots. In accordance with technical recommendations for wheat in central Brazil, it was not necessary to apply lime (EMBRAPA, 2005). Topdressing fertilization (treatment discrimination) was carried out $10 \mathrm{~d}$ after seedling emergence when plants were at the early tillering stage. Soil moisture was at $25 \%$ field capacity at the time of topdressing fertilization. The experiment was irrigated 7 $\mathrm{d}$ after topdressing fertilization with a conventional fixed sprinkler system applying water to a depth of $20 \mathrm{~mm}$.

The experiment was arranged in a $5 \times 2+1$ factorial design applying five $\mathrm{N}$ rates in topdressing, that is, 30 , $60,90,120$, and $150 \mathrm{~kg} \mathrm{~N}^{-1}$ as urea or urea+NBPT (N-(n-butyl)thiophosphoric triamide) (Agrotain ${ }^{\circledR}$, Koch Agronomic Services, Wichita, Kansas, USA) and one control without $\mathrm{N}$ for topdressing. A randomized block experimental design was used with four replicates. Each plot consisted of eight rows 5 min length and with 0.2 $\mathrm{m}$ row spacing. The plot area $\left(3.2 \mathrm{~m}^{2}\right)$ consisted of four central rows in which $0.5 \mathrm{~m}$ were eliminated at both ends of the rows.

Contents of $\mathrm{N}$ were determined in the vegetative aerial part of the plant and in grains during harvest. Thus, 100 stalks were sequentially harvested close to the ground in the central row of the plot. Grains were separated
(A)

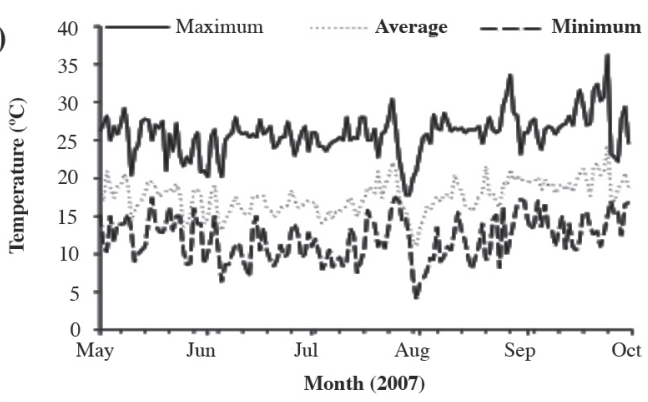

(B)

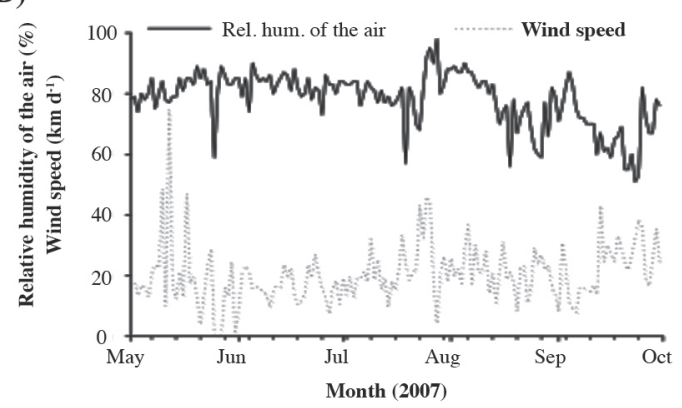

(C)

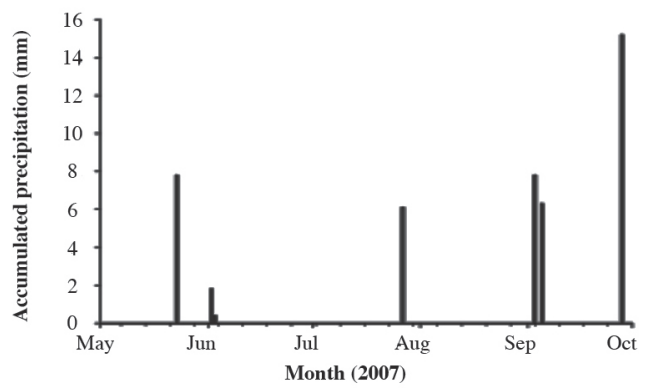

Figure 1. Maximum, average, and minimum temperatures (A); relative air humidity and wind speed $(B)$, and rainfall $(C)$ from May to September 2007. Viçosa, Minas Gerais.

from the vegetative part of the plants by manual ear threshing. Grains and vegetative parts were then dried in a greenhouse with forced-air ventilation until constant mass was achieved and their dry masses were determined. $\mathrm{N}$ content was achieved by the Kjeldahl method. $\mathrm{N}$ contents in the total and vegetative aerial part and in grains were then determined by multiplying the contents of each organ by their respective dry mass.

Apparent nitrogen recovery (ANR) and N use efficiency (NUE) (López-Bellido et al., 2005) were also evaluated.

Table 1. Chemical and physical characteristics of red yellow Oxisol at the Estação Experimental Prof. Diogo Alves de Mello.

\begin{tabular}{|c|c|c|c|c|c|c|c|c|c|c|c|}
\hline \multicolumn{12}{|c|}{ Chemical characteristics } \\
\hline $\mathrm{pH}$ & $P$ & $\mathrm{~K}$ & $\mathrm{Ca}^{2+}$ & $\mathrm{Mg}^{2+}$ & $\mathrm{Al}^{3+}$ & $\mathrm{H}+\mathrm{Al}$ & SB & $\operatorname{CEC}(\mathrm{t})$ & $\operatorname{CEC}(\mathrm{T})$ & V & OM \\
\hline $\mathrm{H}_{2} \mathrm{O}$ & - & - & & & & $\mathrm{cmolcL}^{-1}$ & & & - & $\%$ & $\mathrm{~g} \mathrm{~kg}^{-1}$ \\
\hline 5.4 & 25.2 & 120 & 2.9 & 0.5 & 0.0 & 4.29 & 3.71 & 3.71 & 8.00 & 46 & 14 \\
\hline \multicolumn{12}{|c|}{ Physical characteristics } \\
\hline Sand & & Silt & & Clay & \multicolumn{2}{|c|}{ Texture } & \multicolumn{2}{|c|}{ Density } & $\mathrm{FC}$ & & WP \\
\hline 300 & & $\begin{array}{r}\mathrm{g} \mathrm{kg}^{-1} \\
170\end{array}$ & & $\overline{530}$ & \multicolumn{2}{|c|}{ Clay } & \multicolumn{2}{|c|}{$\mathrm{kg} \mathrm{dm}^{-3}$} & 0.372 & $\mathrm{~kg} \mathrm{~kg}^{-1}$ & $\overline{0.221}$ \\
\hline
\end{tabular}

pH $\left(\mathrm{H}_{2} \mathrm{O}-1: 2.5\right) ; \mathrm{Ca}^{2+}, \mathrm{Mg}^{2+}$ and $\mathrm{Al}^{3+}$ : extractor $\mathrm{KCl} 1 \mathrm{~mol} \mathrm{~L}^{-1} ; \mathrm{P}$ and K: extractor Mehlich ${ }^{-1} ; \mathrm{H}+\mathrm{Al}$ : extractor calcium acetate $0.5 \mathrm{~mol} \mathrm{~L}^{-1}$ at $\mathrm{pH}^{7.0}$.

SB: Sum of bases; $\mathrm{CEC}(\mathrm{t})$ : effective cation exchange capacity; $\mathrm{CEC}(\mathrm{T})$ : cation exchange capacity at $\mathrm{pH}$ 7.0; V: base saturation; OM: organic matter; FC: field capacity; WP: wilting point. 
ANR was achieved by the indirect method by considering that the quantity of $\mathrm{N}$ in the control represented soil $\mathrm{N}$ (natural) and was applied as sowing fertilization. The difference in the quantity of $\mathrm{N}$ in the control in relation to the treatments represents $\mathrm{N}$ from fertilizer for topdressing according to the following equation:

ANR $=(\mathrm{N}$ content in aerial part $-\mathrm{N}$ content in control $) \times 100$ $(\%)=\frac{\text { Quantity of } \mathrm{N} \text { applied }}{\text { (N) }}$

Nitrogen use efficiency was determined by the ratio between the quantity of grains produced (at $13 \%$ humidity) and the quantity of $\mathrm{N}$ applied according to the equation:

NUE $\left(\mathrm{kg}_{\text {grain }} \mathrm{kg}^{-1} \mathrm{~N}\right)=\frac{(\text { Grain yield }- \text { Control grain yield })}{\text { Quantity of } \mathrm{N} \text { applied }\left(\mathrm{kg} \mathrm{ha}^{-1}\right)}$

Besides the previously mentioned characteristics, the following agronomic aspects were also evaluated: plant height, number of grains per ear, shoot dry mass, harvest index, 1000 grain weight, hectoliter mass, number of ears per square meter, and grain yield.

Plant height was determined by randomly evaluating 15 plants per plot; measurements were from the collar to the apex of the ear and excluded awns. The number of grains per ear, shoot dry mass, and harvest index were determined in 100 stalks sequentially collected from the plot's central row. The 1000 grain weight was determined by averaging eight replicates of 100 grains each. Hectoliter mass was determined with a specific scale and from grains collected from the plot. The number of ears per square meter was determined by direct counting three random row segments of $1 \mathrm{~m}$ in the plot. Grain yield (at 13\% humidity) was determined based on grains harvested from the plot and converted into $\mathrm{kg} \mathrm{ha}^{-1}$.

Data were subjected to ANOVA $(\mathrm{p} \leq 0.05)$. Treatment means with urea or urea+NBPT were compared by Tukey's test ( $\mathrm{p} \leq 0.05)$, moreover, means were contrasted with the control by Dunnett's test $(\mathrm{p} \leq 0.05)$. The effects of the rates were studied by regression analyses in which mathematical models were chosen according to the equations with better adjustments, confirmed by the highest values of the coefficients of determination $\left(R^{2}\right)$, and by the significance of regression coefficients and F-test $(p \leq 0.10)$. The significance of the coefficients are shown in the equations by $*(\mathrm{p} \leq 0.10)$ and $* *(\mathrm{p} \leq$ $0.05)$.

\section{RESULTS AND DISCUSSION}

The evaluated characteristics were not affected by the interaction of factors, with the exception of grain yield and grain $\mathrm{N}$ content. Therefore, only these two traits exhibited statistical analysis unfolding. Only the simple effects of the factors were shown for the other characteristics (Table 2).

Treatments did not differ from the control for harvest index, number of ears per square meter (from urea), grain

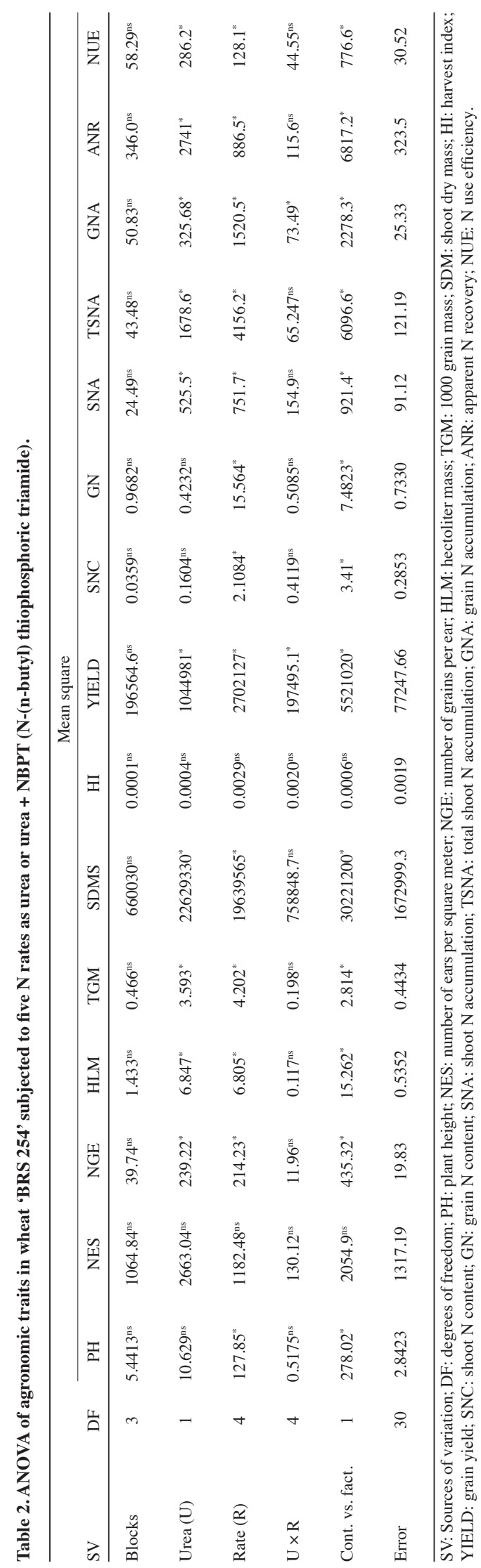


yield, and grain $\mathrm{N}$ content (both from urea at $30 \mathrm{~kg} \mathrm{ha}^{-1}$ rate). These results suggest that topdressing fertilization promotes significant increases in the vegetative and yield components.

Urea and urea+NBPT exhibited similar plant heights, number of ears per square meter, 1000 grain weights, and harvest indexes. The number of grains per ear, mass per hectoliter, and plant shoot dry mass that received urea+NBPT were higher than those fertilized with urea (Table 3). Although there was no difference for some characteristics, results suggest higher $\mathrm{N}$ recovery by plants that received urea + NBPT.

Plants fertilized with urea+NBPT had higher total shoot $\mathrm{N}$ accumulation (TSNA), ANR, and NUE than plants that received only urea. Urea and urea+NBPT treatments exhibited similar shoot $\mathrm{N}$ content (SNC), grain $\mathrm{N}$ content $(\mathrm{GN})$, and shoot $\mathrm{N}$ accumulation (SNA) (Table 4). Results indicate that wheat plants that received urea+NBPT had higher $\mathrm{N}$ recovery because NBPT minimizes $\mathrm{NH}_{3}$ volatilization (Gioacchini et al.,
2002); it therefore promotes higher $\mathrm{N}$ availability in the soil for plant absorption.

Grain yield of the plants fertilized with urea+NBPT was higher than for those that received only urea at the 90 and $120 \mathrm{~kg} \mathrm{~N} \mathrm{ha}^{-1}$ rates (Table 5). This result reflects the higher number of grains per ear and hectoliter mass observed in the urea+NBPT treatment (Table 3) and indicates that this treatment promoted higher plant $\mathrm{N}$ availability at these rates. Increased grain yield for maize (Zea mays L.) was also observed when using NBPT with urea (Chien et al., 2009). The increase reported by these authors was only $351 \mathrm{~kg}$ $\mathrm{ha}^{-1}$, which indicates that gains stimulated by urease inhibitors may be small.

Similar to what occurred with grain yield, grain $\mathrm{N}$ accumulation at the 60,90 , and $120 \mathrm{~kg} \mathrm{ha}^{-1}$ rates was higher when plants received urea+NBPT (Table 5). This behavior reflects a higher grain yield since grain $\mathrm{N}$ content did not vary significantly with the fertilizers under study (Table 4).

Table 3. Agronomic characteristics of wheat 'BRS 254' plants subjected to urea or urea+NBPT(N-(n-butyl) thiophosphoric triamide) application.

\begin{tabular}{lccccccc}
\hline & \multicolumn{5}{c}{ Evaluated characteristics } \\
\cline { 2 - 8 } Treatments & PH & NES & NGE & HM & TGM & SDM & HI \\
\hline & $\mathrm{cm}$ & & & $\mathrm{kg} \mathrm{hL}^{-1}$ & $\mathrm{G}$ & $\mathrm{kg} \mathrm{ha}^{-1}$ & \\
Urea & $95.12 \mathrm{~A}^{*}$ & $345.90 \mathrm{~A}^{\text {ns }}$ & $43.06 \mathrm{~B}^{*}$ & $77.51 \mathrm{~B}^{*}$ & $35.08 \mathrm{~A}^{*}$ & $12935 \mathrm{~B}^{*}$ & $0.3970 \mathrm{~A}^{\text {ns }}$ \\
Urea+NBPT & $96.15 \mathrm{~A}^{*}$ & $362.22 \mathrm{~A}^{*}$ & $47.95 \mathrm{~A}^{*}$ & $78.34 \mathrm{~A}^{*}$ & $34.48 \mathrm{~A}^{*}$ & $14439 \mathrm{~A}^{*}$ & $0.3906 \mathrm{~A}^{\text {ns }}$ \\
\hline Control & 86.89 & 330.28 & 34.56 & 79.97 & 35.66 & 10804 & 0.38 \\
CV, $\%$ & 1.79 & 10.31 & 4.33 & 0.94 & 1.91 & 10.63 & 11.12 \\
\hline
\end{tabular}

PH: Plant height; NES: number of ears per square meter; NGE: number of grains per ear; HLM: hectoliter mass; TGM:1000 grain mass; SDM: shoot dry mass; and HI: harvest index.

Means followed by the same letter in the column do not differ according to Tukey's test $(\mathrm{p} \leq 0.05)$.

"Different from control.

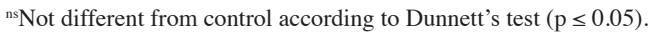

Table 4. Nitrogen recovery by wheat 'BRS 254' plants subjected to urea or urea+NBPT(N-(n-butyl) thiophosphoric triamide) application.

\begin{tabular}{llllcrr}
\hline & \multicolumn{5}{c}{ Evaluated characteristics } \\
\cline { 2 - 6 } Treatments & SNC & GN & SNA & TSNA & ANR & NUE \\
\hline & $\mathrm{g} \mathrm{kg}^{-1}$ & $\mathrm{~g} \mathrm{~kg}^{-1}$ & $\mathrm{~kg} \mathrm{ha}^{-1}$ & $\mathrm{~kg} \mathrm{ha}^{-1}$ & $\%$ & $\mathrm{~kg} \mathrm{~kg}^{-1}$ \\
Urea & $4.51 \mathrm{~A}^{*}$ & $19.86 \mathrm{~A}^{*}$ & $42.05 \mathrm{~A}^{*}$ & $106.43 \mathrm{~B}^{*}$ & $35.02 \mathrm{~B}$ & $11.17 \mathrm{~B}$ \\
Urea+NBPT & $4.63 \mathrm{~A}^{*}$ & $19.93 \mathrm{~A}^{*}$ & $49.30 \mathrm{~A}^{*}$ & $119.38 \mathrm{~A}^{*}$ & $51.57 \mathrm{~A}$ & $16.52 \mathrm{~A}$ \\
\hline Control & 3.60 & 18.45 & 29.75 & 71.96 & 0.00 & 0.00 \\
CV, $\%$ & 11.90 & 4.33 & 21.58 & 10.08 & 45.69 & 43.87 \\
\hline
\end{tabular}

SNC: Shoot N content; GN: Grain N content; SNA: Shoot N accumulation; TSNA: total shoot N accumulation; ANR: Apparent N recovery; NUE: N use efficiency. Means followed by the same letter in the column do not differ according to Tukey's test ( $\mathrm{p} \leq 0.05)$.

"Different from control.

Table 5. Grain yield and N content in wheat 'BRS 254' grains subjected to urea or urea+NBPT(N-(n-butyl) thiophosphoric triamide) application.

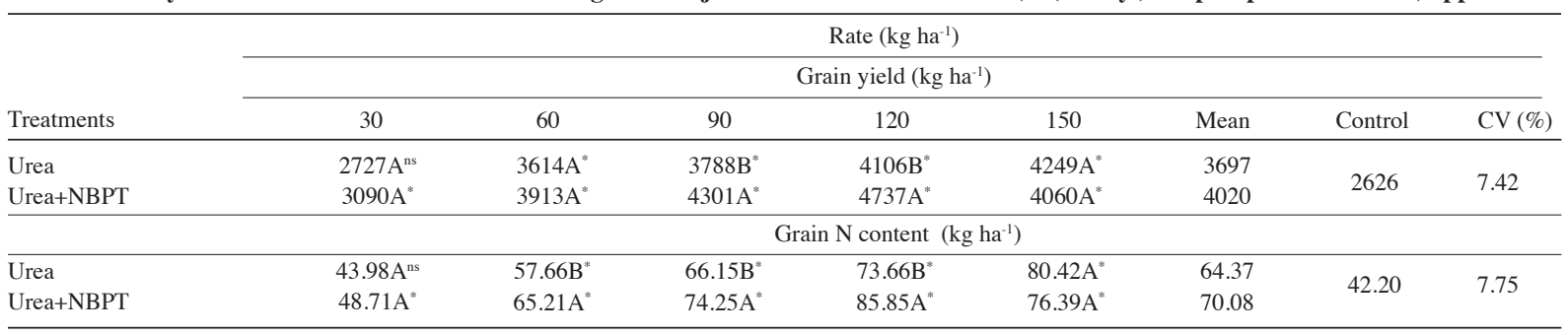

Means followed by the same letter in the column do not differ according to Tukey's test ( $\mathrm{p} \leq 0.05$ ).

"Different from control.

$\left.{ }^{\text {ns } N o t ~ d i f f e r e n t ~ f r o m ~ c o n t r o l ~ a c c o r d i n g ~ t o ~ D u n n e t t ' s ~ t e s t ~(~} \mathrm{p} \leq 0.05\right)$. 
The $\mathrm{N}$ rates promoted a linear increase in plant height and shoot dry mass (Figures 2A and 2E), a quadratic response in the number of grains per ear (Figure 2B), and linear decreases in 1000 grain weight and mass per hectoliter (Figure 2C and 2D).

Height and shoot dry mass increase because $\mathrm{N}$ contributes to plant vegetative growth, thus affecting the rates of leaf emergence and expansion, final leaf size, and stem elongation in cereals (Schröder et al., 2000). Increases in the vegetative characteristics are beneficial because they represent reserves that will be used during grain filling.

The increase in the number of grains per ear is similar to that reported for wheat in the same location (Espindula et al., 2010) and for rice (Oryza sativa L.) (Buzetti et al., 2006) since higher $\mathrm{N}$ rates promote higher vegetative vigor in the differentiation stage of the reproductive meristem, which results in a higher quantity of differentiated flowers. The quadratic response is associated to reaching the cultivar's maximum genetic potential.

The reduction in 1000 grain weight and hectoliter mass is similar to the results reported for wheat (Marino et al.,
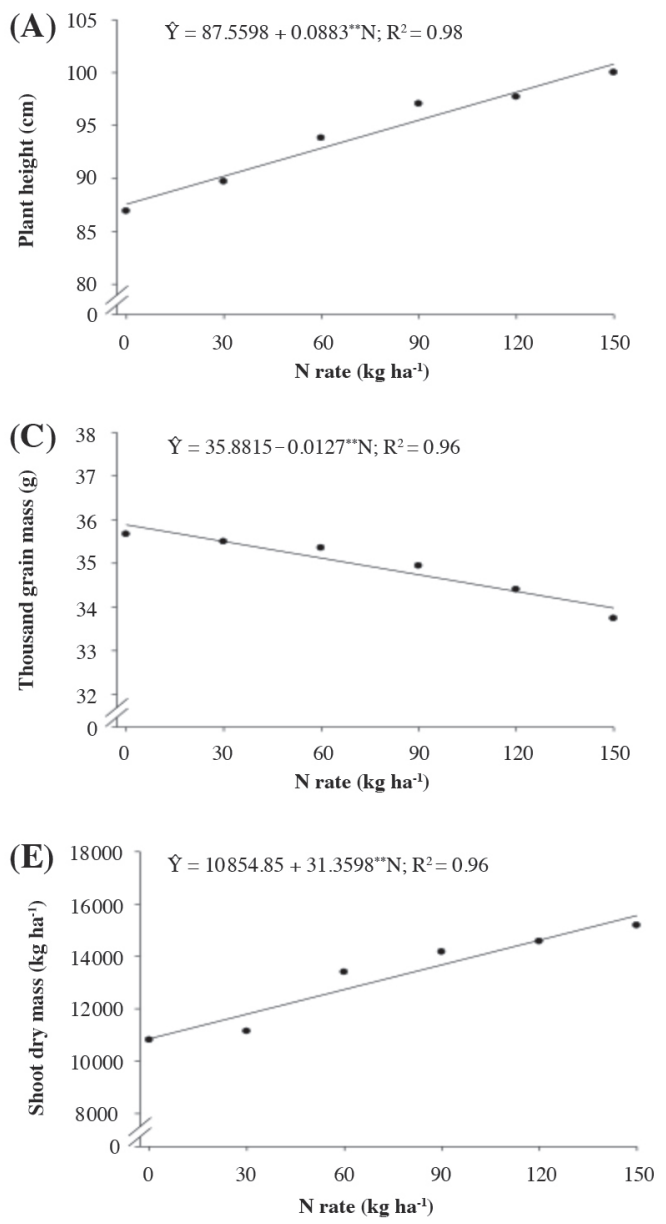

2009). This behavior is mainly due to the compensatory effect between the number of grains and grain mass. In other words, the increase in number of grains per ear (Figure 2B) reduces grain mass and mass per hectoliter.

Grain yield increased linearly with the urea rates and responded in a quadratic way with the urea + NBPT rates (Figure 2F). The maximum yield point for the urea+NBPT treatment was $4400 \mathrm{~kg} \mathrm{ha}^{-1}$, which was achieved with 118 $\mathrm{kg} \mathrm{N} \mathrm{ha}^{-1}$.

Increased grain yields are associated to higher $\mathrm{N}$ absorption (Figure 3), higher values of vegetative growth (Figures 2A and 2E), and number of grains per ear (Figure 2B). The difference between the behavior of urea and urea+NBPT is due to N availability. For the urea+NBPT treatment, rates promoted increases up to the maximum yield (achieved with $118 \mathrm{~kg} \mathrm{~N} \mathrm{ha}^{-1}$ ) after which there was a decrease due to genetic limitations and excessive vegetative growth (Espindula et al., 2009). On the other hand, plants that received only urea did not exhibit a maximum yield until reaching the $150 \mathrm{~kg} \mathrm{~N}^{-1}$ rate because they presented a linear increase in grain yield. This difference is related to $\mathrm{N}$ losses by $\mathrm{NH}_{3}$ volatilization.
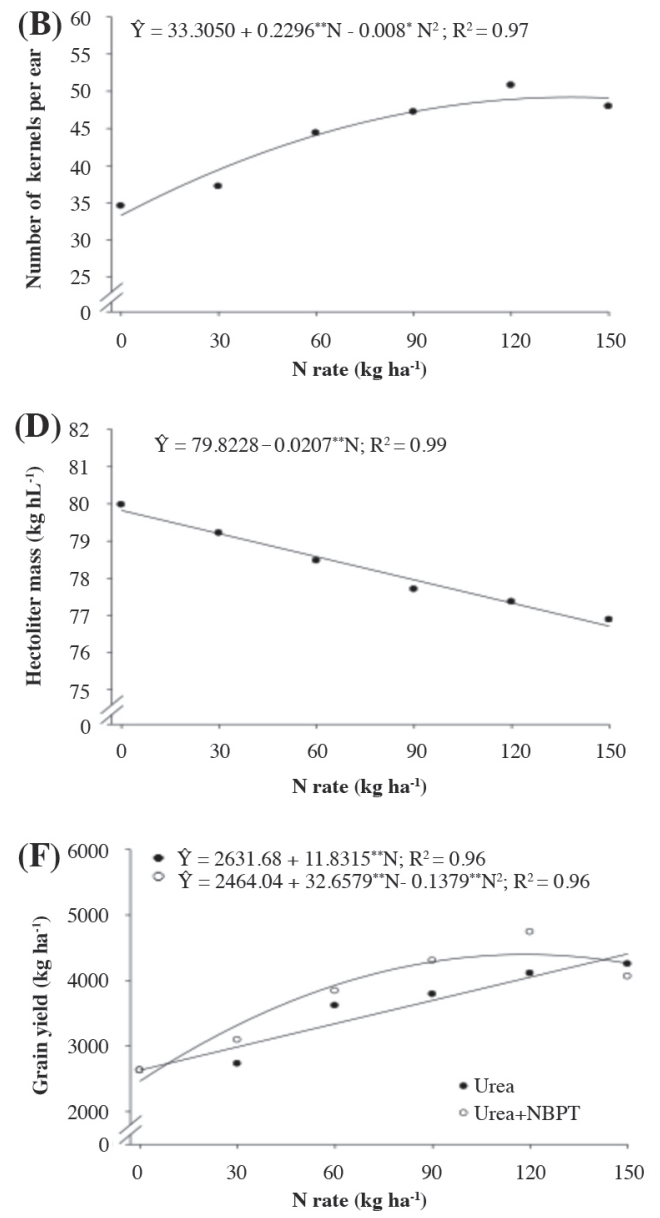

Figure 2. Agronomic characteristics of wheat 'BRS 254' plants subjected to N rates as urea and/or urea+NBPT (N-(n-butyl) thiophosphoric triamide). 

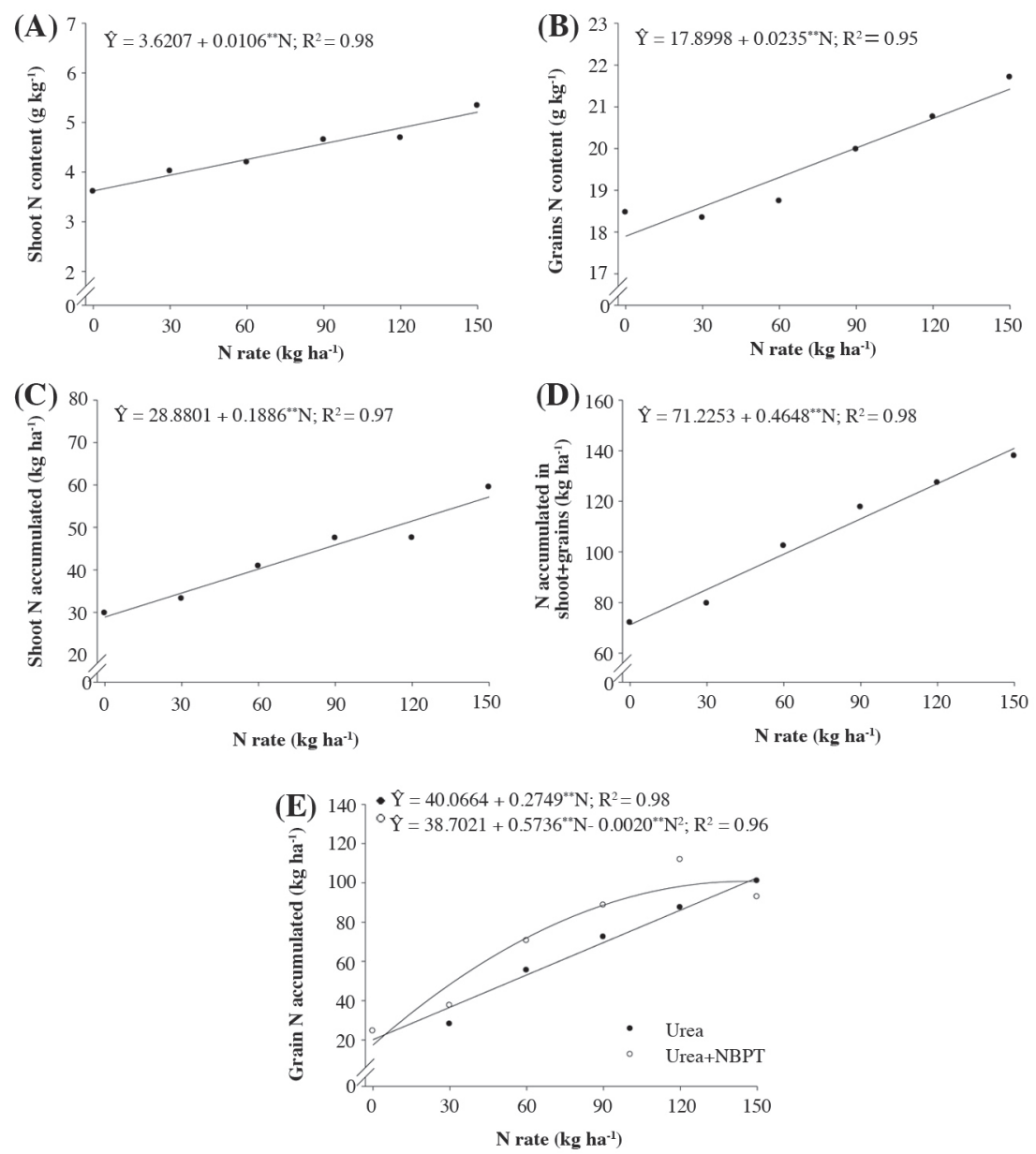

Figure 3. Shoot $\mathrm{N}$ content (A), grain (B), $\mathrm{N}$ content accumulation in the vegetative aerial part (C), total aerial part (D), and in grains (E) wheat 'BRS 254' plants subjected to $\mathrm{N}$ rates as urea and urea+NBPT ( $\mathrm{N}$-(n-butyl) thiophosphoric triamide).

Nitrogen content in shoot, grain, vegetative shoot, and total aerial part increased linearly with increased $\mathrm{N}$ rates. Grain $\mathrm{N}$ content increased linearly with the $\mathrm{N}$ rates for urea and exhibited a quadratic variation for urea+NBPT (Figure 3).

Nitrogen contents increased due to the increase in the

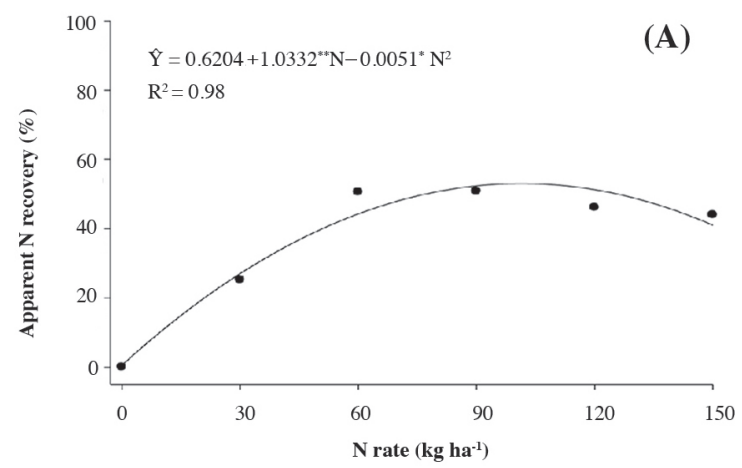

availability of this nutrient in the soil and results agree with those reported in the literature (Kolchinski and Schuch, 2003; Lopez-Bellido et al., 2004; Sepaskhah and Hosseini, 2008; Marino et al., 2009). However, increased $\mathrm{N}$ content in the mass of the vegetative and total aerial parts is due to both the increased content and increased

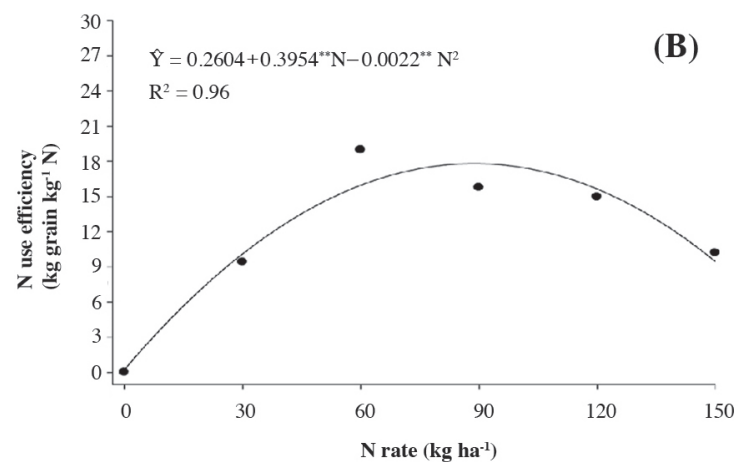

Figure 4. Apparent $\mathrm{N}$ recovery (ANR) (A) and $\mathrm{N}$ use efficiency (NUE) (B) of wheat 'BRS 254' plants subjected to $\mathrm{N}$ rates as urea and urea+NBPT (N-(n-butyl) thiophosphoric triamide). 
mass of the aerial part and grain yield. Similarly, results for grain $\mathrm{N}$ content reflect the behavior of grain yield and suggest increased nutrient export by the grains when applied $\mathrm{N}$ rates are higher.

Apparent nitrogen recovery (ANR) showed a quadratic variation with increased $\mathrm{N}$ rates and a maximum point of $58 \%$, which was achieved by applying $101 \mathrm{~kg} \mathrm{~N}^{-1}$ (Figure 4A). Apparent $\mathrm{N}$ recovery measures plant efficiency to recover the nutrient applied to the soil (Good et al., 2004); results indicate that plants satisfactorily absorb $\mathrm{N}$ provided by fertilization up to the rate of $\approx 100$ $\mathrm{kg} \mathrm{ha}^{-1}$ after which the nutrient is not properly utilized and higher rates are not recommended. Reduced ANR was also found when the 90 and $180 \mathrm{~kg} \mathrm{ha}^{-1}$ rates were used in wheat plants (Sepaskhah and Hosseini, 2008).

Nitrogen use efficiency showed a quadratic variance with increased $\mathrm{N}$ rates with a maximum point of $18 \mathrm{~kg}$ grain $\mathrm{kg}^{-1} \mathrm{~N}$ supplied, which was achieved by applying 90 $\mathrm{kg} \mathrm{N} \mathrm{ha}^{-1}$ (Figure 4B). Decreased NUE was also achieved for white oat subjected to $\mathrm{N}$ rates by measuring absorption efficiency, remobilization, and fertilization (Kolchinski and Schuch, 2003). Nitrogen use efficiency reflects the quantity of grains produced per unit of $\mathrm{N}$ supplied (Good et al., 2004). Therefore, the results found in this study suggest that plants do not use this nutrient efficiently under high $\mathrm{N}$ rates because plants invest excessively in vegetative structures and do not efficiently remobilize this nutrient to the grains at the filling stage above a certain level of $\mathrm{N}$ supply; this phenomenon is known as luxury consumption.

\section{CONCLUSIONS}

Adding urease inhibitor NBPT together with urea allows higher N uptake by wheat 'BRS 254' plants as well as higher grain yield.

The $100 \mathrm{~kg} \mathrm{~N} \mathrm{ha}^{-1}$ rate allows the best apparent $\mathrm{N}$ recovery and the $90 \mathrm{~kg} \mathrm{ha}^{-1}$ rate provides the best $\mathrm{N}$ use efficiency by wheat 'BRS 254'plants.

\section{ACKNOWLEDGEMENTS}

The authors wish to acknowledge the "Conselho Nacional de Desenvolvimento Científico e Tecnológico" (CNPq) and "Fundação de Amparo à Pesquisa do Estado de Minas Gerais" (FAPEMIG) for providing scholarships and financial support. We also thank Fertipar Sudeste Adubos e Corretivos Agrícolas Ltda. and Agrotain International LLC for their assistance.

\section{LITERATURE CITED}

Buzetti, S., G.C. Bazanini, J.G. Freitas, M. Andreotti, O. Arf, E. Sá, e F.A. Meira. 2006. Resposta de cultivares de arroz a rates de nitrogênio e do regulador de crescimento cloreto de clormequat. Pesquisa Agropecuária Brasileira 41:1731-1737.
Cantarella, H., P.C.O. Trivelin, T.L.M. Contin, F.L.F. Dias, R Rossetto, R. Marcelino, et al. 2008. Ammonia volatilization from urease inhibitor-treated urea applied to sugarcane trash blankets. Scientia Agricola 65:397-401.

Chien, S.H., L.I. Prochnow, and H. Cantarella. 2009. Recent developments of fertilizer production and use to improve nutrient efficiency and minimize environmental impacts. Advances in Agronomy 102:267-322.

Costa, M.C.G., G.C. Vitti, e H. Cantarella. 2003. Volatilização de $\mathrm{N}-\mathrm{NH}_{3}$ de fontes nitrogenadas em cana-de-açúcar colhida sem despalha a fogo. Revista Brasileira de Ciência do Solo 27:631637.

EMBRAPA. 2005. Informações técnicas para a cultura de trigo na Região do Brasil Central: safras 2005 e 2006.82 p. In Reunião da Comissão Centro Brasileira de Pesquisa de Trigo, Goiânia, Goiás. 2004. (Documentos/Embrapa Arroz e feijão, ISSN 1516-7518; 173).

Espindula, M.C.,V.S. Rocha, P.C.R. Fontes, R.C.C. Silva, and L.T. Souza. 2009. Effect of nitrogen and trinexapac-ethyl rates on the spad index of wheat leaves. Journal of Plant Nutrition 32:19561964.

Espindula, M.C., V.S. Rocha, M.A. Souza, J.A.S. Grossi, e L.T. Souza. 2010. Doses e formas de aplicação de nitrogênio no desenvolvimento e produção da cultura do trigo. Ciência e Agrotecnologia 34:1404-1411.

Espindula, M.C., V.S. Rocha, L.T. Souza, M.A. Souza, M Campanharo, and J.A.S. Grossi. 2011. Rates of nitrogen and growth retardant trinexapac-ethyl on wheat. Ciência Rural 41:2045-2052.

Gioacchini, P., A. Nastri, C. Marzadori, C. Giovannini, L.V. Antisari, and C. Gessa. 2002. Influence of urease and nitrification inhibitors on $\mathrm{N}$ losses from soils fertilized with urea. Biology and Fertility of Soils 36:129-135.

Good, A.G., A.K. Shrawat, and D.G. Muench. 2004. Can less yield more? Is reducing nutrient input into the environment compatible with maintaining crop production? Trends in Plant Science 9:597605.

Grant, C.A., and L.D. Bailey. 1999. Effect of seed-placed urea fertilizer and n-(n-butyl) thiophosphoric triamide (NBPT) on emergence and grain yield of barley. Canadian Journal of Plant Science 79:491-496.

Kolchinski, E.M., e L.O.B. Schuch. 2003. Eficiência no uso do nitrogênio por cultivares de aveia branca de acordo com a adubação nitrogenada. Revista Brasileira de Ciência do Solo 27:1033-1038.

Krajewska, B. 2009. Ureases I. Functional, catalytic and kinetic properties: A review. Journal of Molecular Catalysis B: Enzimatic 59:9-21.

Longo, R.M., e W.J. Melo. 2005. Hidrólise da uréia em latossolos: efeito da concentração de uréia, temperatura, $\mathrm{pH}$, armazenamento e tempo de incubação. Revista Brasileira de Ciência do Solo 29:651-657.

López-Bellido, L., R.J. Lopez-Bellido, and R. Redondo. 2005. Nitrogen efficiency in wheat under rainfed Mediterranean conditions as affected by split nitrogen application. Field Crops Research 94:86-97.

Lopez-Bellido, R.J., C.E. Shepherd, and P.B. Barraclough. 2004. Predicting post-anthesis $\mathrm{N}$ requirements of bread wheat with a Minolta SPAD meter. European Journal of Agronomy 20:313-320.

Malhi, S.S., C.A. Grant, A.M. Johnston, and K.S. Gill. 2001. Nitrogen fertilization management for no-till cereal production in the Canadian Great Plains: a review. Soil \& Tillage Research 60:101-122.

Manunza, B., S. Deiana, M. Pintore, and C. Gessa. 1999. The binding mechanism of urea, hydroxamic acid and N-(N-butyl)-phosphoric triamide to the urease active site. A comparative molecular dynamics study. Soil Biology and Biochemistry 31:789-796.

Marino, S., R. Tognetti, and A. Alvino. 2009. Crop yield and grain quality of emmer populations grown in central Italy, as affected by nitrogen fertilization. European Journal of Agronomy 31:233-240. 
Martha Jr., G.B., M. Corsi, P.C.O. Trivelin, L. Vilela, T.L.F. Pinto, G.M. Teixeira, et al. 2004. Perda de amônia por volatilização em pastagem de capim-tanzânia adubada com uréia no verão. Revista Brasileira de Zootecnia 33:2240-2247.

Rodrigues, M.B., e J.C. Kiehl. 1992. Distribuição e nitrificação da amonia proveniente da ureia aplicada ao solo. Revista Brasileira de Ciência do Solo 16:403-408.

Schröder, J.J., J.J. Neeteson, O. Oenema, and P.C. Struik. 2000. Does the crop or the soil indicate how to save nitrogen in maize production?: Reviewing the state of the art. Field Crops Research 66:151-164.
Sepaskhah,A.R., and S.N. Hosseini. 2008. Effects of alternate furrow irrigation and nitrogen application rates on yield and water- and nitrogen-use efficiency of winter wheat (Triticum aestivum L.) Plant Production Science 11:250-259.

Trindade, M.G., L.F. Stone, A.B. Heinemann, A.D. Cánovas, e J.A.A. Moreira. 2006. Nitrogênio e água como fatores de produtividade do trigo no cerrado. Revista Brasileira de Engenharia Agrícola e Ambiental 10:24-29.

Vitti, A.C., P.C.O. Trivelin, G.J.C. Gava, H.C.J. Franco, I.R. Bologna, e C.E. Faroni. 2007. Produtividade da cana-de-açúcar relacionada à localização de adubos nitrogenados aplicados sobre os resíduos culturais em canavial sem queima. Revista Brasileira Ciência do Solo 31:491-498. 